The Digital Object Identifier - DOI: 10.37952/ROI-jbc-01/19-59-9-82

Submitted on September 14, 2019.

\title{
Antifungal and growth-promoting activity of the main waste of the lignocellulosic hydrolysates biodetoxification
}

\author{
(C) Tatiana S. Morozova, ${ }^{{ }^{+}}$Elizaveta V. Kuznecova, and Sergey Yu. Semyonov \\ Biological Institute. National Research Tomsk State University. Lenin Ave., 36. Tomsk, 634050. \\ Tomsk Region. Russia.Phone: +7 (953)925-83-85. E-mail: tsmorozova1991@gmail.com
}

\section{*Supervising author; ${ }^{+}$Corresponding author}

Keywords: waste of lignocellulosic hydrolysates biodetoxification, activated sludge, plant protection, wheat, root rot, biofungicide, growth stimulator.

The antifungal and growth-stimulating activity of biological detoxification waste products of hydrolysates of lignocellulosic raw materials in vitro and in vivo was evaluated in comparison with reference preparations (Alirin-B, Fitosporin-M) and control (sterile tap water). These wastes are specially adapted microbocenoses of activated sludge, worked out in the process of purification of hydrolyzates of lignocellulosic raw materials from inhibitors of acetone butyl fermentation. The agronomic value of biodetoxification waste was studied in three prototypes of different nature, using Iren spring wheat as an example. The results showed that detoxification bioagents, regardless of origin, showed fungistatic activity at the in vitro and in vivo study stages (biotest). In an in vitro experiment, all test samples showed significant antifungal activity against the fungus $F$. oxysporum. The most effective was the biodetoxification waste obtained on the basis of microbocenosis of activated sludge grown on a nutrient medium containing phenol, formic and acetic acid. As a result of exposure to this bioagent at the end of the experiment, the average diameter of the colonies of the fungus $F$. oxysporum was approximately 34 times less than in the control version. The detoxification bioagent, obtained on the basis of a specially adapted microbocenosis of activated sludge grown on a nutrient medium simulating wastewater, reduced the diameter of phytopathogenic fungus colonies by an average of 16 times. Specially adapted activated sludge from the sewage treatment facilities of the wood processing enterprise, worked out during the detoxification of hydrolysates of lignocellulosic raw materials, was also able to effectively suppress fungus growth, the average diameter of which was 19 times less than the control. The biotest results also confirmed the fungistatic activity of the test samples. The effectiveness of reducing the total infection with seminal infections in different experimental variants ranged from 52 to $84 \%$. The growth-promoting ability of biodetoxification waste was weak.

\section{References}

[1] A.N. Igoshin. The need for grain and the current state of grain production of the Nizhny Novgorod region. Bulletin NGIEI. 2013. Vol.22. No.3. P.62-75. (russian)

[2] G.A. Filenko, T.I. Firsova. Sown area and winter wheat yield. Agrarian Bulletin of the Urals. 2016. Vol.148. No.6. P.61-69. (russian)

[3] T.A. Avseeva, E.V. Zolotaryova, N.E. Savchenko. Techniques for increasing the yield of spring wheat in the conditions of the middle Amur region. Eurasian Union of Scientists. 2014. Vol.10. No.8. P.68-71. (russian)

[4] A.V. Ovsyankina. Root rot of cereals. Theory and practice of animal parasitic diseases. 2012. No.13. P.300-303. (russian)

[5] E.A. Ivantsova. Diseases of grain crops. Farmer. Volga region. 2015. Vol.38. No.7. P.36-38. (russian)

[6] V.B. Ekimova, O.A. Dregval, A.I. Vinnikov. Assessment of infection of phytopathogenic fungi of cereals in the forest-steppe zone of Ukraine. Biological Bulletin of the Melitopol State Pedagogical University named after Bogdan Khmelnitsky. 2014. Vol.4. No.3. P.85-97. (russian)

[7] L.D. Grishechkina, V.I. Dolzhenko. Microbiological preparations for the protection of wheat from pathogens of fungal diseases. Agrochemistry. 2017. No.3. P.81-91. (russian)

[8] G.R. Kudoyarova, I.K. Kurdish, A.I. Melentyev. The formation of phytohormones by soil and rhizospheric bacteria as a factor in stimulating plant growth. Bulletin of the Ufa Scientific Center of the Russian Academy of Sciences. 2011. No.3-4. P.5-16. (russian) 
ANTIFUNGAL AND GROWTH-PROMOTING ACTIVITY OF THE MAIN WASTE OF THE LIGNOCELLULOSIC ... 82-92

[9] N. Ohkama-Ohtsu, J. Wasaki. Recent Progress in Plant Nutrition Research: Cross-Talk Between Nutrients, Plant Physiology and Soil Microorganisms. Plant and Cell Physiology. 2010. Vol.51(8). P.1255-1264.

[10] L.C. Van Loon. Plant responses to plant growth-promoting rhizobacteria. European Journal of Plant Pathology. 2007. Vol.119. No.3. P.243-254.

[11] I.V. Maksimov, S.V. Veselova, T.V. Nuzhnaya, E.R. Sarvarova, R.M. Khayrullin. Bacteria stimulating plant growth in the regulation of plant resistance to stress factors. Plant Physiology. 2015. No.6. P.763775. (russian)

[12] M. Rosenblueth, E. Martínez-Romero. Bacterial endophytes and their interactions with hosts. Mol. Plant-Microbe Interact. 2006. Vol.19. P.827-837.

[13] N. Weyens, D. van der Lelie, S. Taghavi, L. Newman, J. Vangronsveld. Exploiting plant-microbe partnerships to improve biomass production and remediation. Trends Biotechnol. 2009. Vol.27. No.10. P.591-996.

[14] F.M. Davletshin, R.G. Gilmanov, H.M. Safin, D.S. Ayupov. The effectiveness of the biofungicide Phytosporin-M, Zh on spring wheat with direct sowing. Achievements of science and technology of the agricultural sector. 2014. No.2. P.39-40. (russian)

[15] T.V. Holdobina. Realization of the potential productivity of spring wheat when using bactofite as an antidepressant. Innovative development of the agricultural sector. 2016. Vol.12. No.2. P.11-14. (russian)

[16] O.P. Gorbunov. Improvement of drugs based on Pseudomonas aurefaciens. Protection and Plant Quarantine. 2011. No.5. P.35-36. (russian)

[17] Z.G. Milovanova, D.A. Kolesova, Yu.P. Fedulov. The effectiveness of the use of new drugs phytolavin and farmayod for the protection of winter wheat and barley crops from diseases. Transactions of the Kuban State Agrarian University. 2010. No.23. P.95-100. (russian)

[18] G.A. Batalova, E.A. Budina. The use of Agat 25K for the treatment of seeds and crops of spring oats. Russian Agricultural Science. 2008. No.1. P.8-9. (russian)

[19] A.Yu. Kekalo, V.V. Nemchenko., N.Yu. Zargaryan, M.Yu. Tsypysheva. Protection of grain crops from diseases. Kurtamysh: Kurtamysh Printing House. 2017. 172p. (russian)

[20] K.D. Dyatlova. Microbial preparations in crop production. Soros Educational Journal. 2001. No.5. P.17-22. (russian)

[21] A.A. Shagaev, N.A. Zelenova, E.N. Dmitrieva, A.A. Belov, and N.S. Markvichev. Surface cultivation of fungi of the genus Fusarium and Trichoderma with continuous supply of nutrition components. Butlerov Communications. 2017. Vol.50. No.5. P.65-72. DOI: 10.37952/ROI-jbc-01/17-50-5-65

[22] R.I. Frank, V.I. Kishchenko. Biological products in modern agriculture. Protection and quarantine of plants. 2008. No.4. P.30-32. (russian)

[23] I.A. Tikhonovich, A.P. Kozhemyakov, V.K. Chebotar. Biological products in agriculture. Methodology and practice of the use of microorganisms in crop production and fodder production. Moscow: Russian Agricultural Academy. 2005. 154p. (russian)

[24] D.G. Georgakopoulos, P. Fiddaman, C. Leifert, N.E. Malathrakis. Biological control of cucumber and sugar beet damping-off caused by Pythium ultimum with bacterial and fungal antagonists. Journal of applied microbiology. 2002. No.92. P.1078-1086.

[25] D.A. Schisler, P.J. Slinger, R.J. Bothast. Effects of antagonist cell concentration and two-strain mixtures on biological control of Fusarium dry rot of potatoes. J. Phytopathology. 1997. No.87. P.177183.

[26] M. Koutny, J. Ruzicka, J. Chlachula. Screening for phenol-degrading bacteria in the pristine soils of south Siberia. Applied Soil Ecology. 2003. No.23. P.79-83

[27] M.M. Yakimov, I.S. Rogozhin, N.A. Zagustina, A.M. Bezborodov. The bacterial strain Pseudomonas fluorescens, decomposing styrene and ethylbenzene. Patent RF. No. 2067115. Failed: 02.06.1993. Pub. Date: 27.09.1996. (russian)

[28] M.M. Yakimov, A.E. Kurlovich, N.A. Ushakova, I.V. Zaikina, I.S. Rogozhin, A.M. Bezborodov. Bacterial strain Methylobacterium species degrading methanol and/or formaldehyde. Patent RF. No. 2067115. Failed: 26.04.1995. Pub. Date: 20.04.1997. (russian)

[29] O.D. Denis, P.I. Gvozdyak, L.I. Nesinova, G.S. Venhzhen. Consortium of bacterial strains of Basillus megatherium, Bacillus freudenreichii, Agrobacterium sp., Arthrobacter oxamicetus used for sewage treatment of diethylene glycol and methanol. Patent UA. No. 11020. Pub. Date: 25.12.1996.

[30] I.I. Denisov, N.G. Tikhonov, V.I. Ilyukhin. The bacterial strain Pseudomonas cepacia VDK VKPM v7559 - phenol and formaldehyde destructor. Patent RF. No. 2144079. Failed: 04.06.1998. Pub. Date: 10.01.2000. (russian) 
[31] T.V. Fufaeva, N.A. Kazakova. Assessment of the effect of various doses of formaldehyde and phenol on the microorganisms of leached chernozem. Austrian Journal of Technical and Natural Sciences. 2014. No.5-6. P.65-72. (russian)

[32] V.V. Korobov, S.N. Starikov, A.I. Sagitova, E.Yu. Zhurenko, N.V. Zharikova, T.R. Yasakov, T.V. Markusheva. Strains-destructors of phenol of the genus Bacillus of industrial ecotopes. Bulletin of the Ufa Scientific Center of the Russian Academy of Sciences. 2017. No.2. P.73-77. (russian)

[33] E.V. Edokimov, A.V. Evdokimov, M.V. Mironov, I.E. Chekhunova, E.V. Kornievskaya. The bacterial strain Pseudomonas species used to utilize formaldehyde and capable of consuming formaldehyde as the only source of carbon and energy in a poor mineral nutrient medium. Patent RF. No. 22102474. Failed: 09.11.1995. Pub. Date: 20.01.2098. (russian)

[34] O.M. Minaeva, E.E. Akimova, Yu.A. Gushchina, E.V. Evdokimov. Bacteria Pseudomonas sp. B-6798 as antagonists of the growth of phytopathogenic fungi and as plant growth stimulants. Problems of environmental safety and nature management in Western Siberia. Proceedings of TSU, biological series. 2004. No.266. P.55-59. (russian)

[35] T. Morozova, S. Semyonov. Biological Detoxification of Lignocellulosic Hydrolysates for Improved Biobutanol Production. Key Engineering Materials. 2016. Vol.683. P.525-530

[36] T. Morozova, S. Semyonov. Acetone-Butanol Fermentation of Lignocellulosic Hydrolysates for the Butanol Production. AIP Conference Proceedings 1899, 020009. 2017. P.1-6

[37] B. Bratina, A. Šorgo, J. Kramberger, U. Ajdnik, L. Fras Zemljič, J. Ekart, R. Šafarič. From municipal/industrial wastewater sludge and FOG to fertilizer: A proposal for economic sustainable sludge management. Journal of Environmental Management. 2016. No.183(3). P.1009-1025.

[38] A.N. Suciu, L. Lamastra, M. Trevisan. PAHs content of sewage sludge in Europe and its use as soil fertilizer. Waste Management. 2015. Vol.41. P.119-127.

[39] From wastewater to eco-friendly fertilizer. Filtration + Separation. 2016. Vol.53(4). P.18-20.

[40] V.N. Dmitrenko, V.N. Schepotiev, A.S. Frid, O.V. Kutovaya. Use of sewage sludge (activated sludge) from a confectionery factory as fertilizer for floodplain soils. 5-th International scientific and environmental conference dedicated to the 95th anniversary of the Kuban State Agrarian University «Problems of reclamation of household waste, industrial and agricultural production». Russia. March 28-30. 2014. P.121-126. (russian)

[41] A.M. Assonov, O.R. Ilyasov, M.V. Kirillov. Activated sludge of aeration stations - a biological resource of organic fertilizers. Agrarian Bulletin of the Urals. 2012. Vol.96. No.4. P 45-47. (russian).।

[42] A.B. Solodkova, N.A. Sobgayda, I.G. Shaykhiev. Evaluation of the content of chemicals in the soil and in plants when using organic fertilizers from spent activated sludge. Bulletin of the Technological University. 2013. Vol.16. No.6. P.128-130.

[43] P. Vanrolleghem. Principles of Respirometry in Activated Sludge Wastewater Treatment. Proceedings International Workshop on Recent Development in Respirometry for Wastewater Treatment Plant Monitoring and Control. Taipei. Taiwan, October 22-23. 2002. P.20. 